\title{
Participation by Women in the 2000 APSA Meeting
}

\section{Martin Gruberg, University of Wisconsin, Oshkosh}

\begin{abstract}
This is the twenty-ninth year that I have been monitoring participation by women at APSA's Annual Meeting. These $P S$ reports have documented the ascent of women in our profession. (At this year's meeting, I presented a poster session tracing participation by women in our programs since the 1950s.) While there are signs that women have continued to move ahead in their participation, the picture is mixed.
\end{abstract}

As I've noted previously, where women head divisions or panels, there is a greater likelihood of other women being selected for program contributions. This year, a female co-chaired the Program Committee. In 2000, 18 of the 50 division heads were women (36\%) (cf., 1995: 38.8\%; 1996: 30.06\%; 1997: 37.3\%; 1998: $36.2 \%$; 1999: $42.9 \%$ ). The divisions they headed had women as $32.3 \%$ ( 75 of 232 ) of the panel chairs, $36.1 \%$ (353 of 977) of the papergivers, and $28.3 \%$ (84 of 297) of the discussants (cf., 1995: 30.7\%, $34.2 \%$, 31.0\%; 1996: $26.1 \%$, 35.1\%, 29.8\%; 1997: 35.4\%, 32.1\%, 31.4\%; 1998: 31.8\%, 38.8\%, 36.7\%; 1999: $29.1 \%, 29.6 \%, 28.4 \%$ ).

The convention divisions led by women had $49.3 \%$ of the convention's female panel chairs, $48.8 \%$ of the papergivers, and $52.8 \%$ of its discussants (cf., 1995: 44.0\%, 48.0\%, 42.0\%; 1996: 40.4\%, 48.1\%, 50.7\%; 1997: 60.1\%, 54.0\%, 53.4\%; 1998: $59.1 \%, 51.0 \%, 49.7 \%$; 1999: 54.7\%, $51.5 \%, 53.8 \%$ ). Women-chaired panels had $41.9 \%$ female papergivers and $42.2 \%$ female discussants (cf., 1995: 41.0\%, 42.5\%; 1996: 38.7\%, 33.9\%; 1997: 37.7\%, 43.0\%; 1998: 41.1\%, 49.4\%; 1999: 38.7\%, 45.3\%). These constituted $37.3 \%$ of the women giving papers at the 2000 convention and $44.0 \%$ of the women serving as discussants (cf., 1995: 40.8\%, 43.3\%; 1996: 30.9\%, 30.3\%; In recent years, poster session presentations have been added to

\begin{tabular}{|c|c|c|c|}
\hline \multicolumn{4}{|c|}{ Chairpersons } \\
\hline Year & Total & Women & $\%$ \\
\hline 1971 & 154 & 12 & 7.8 \\
\hline 1981 & 137 & 16 & 11.7 \\
\hline 1991 & 439 & 107 & 24.4 \\
\hline 1992 & 463 & 106 & 22.9 \\
\hline 1993 & 452 & 115 & 25.4 \\
\hline 1994 & 509 & 164 & 32.2 \\
\hline 1995 & 480 & 134 & 27.9 \\
\hline 1996 & 517 & 136 & 26.3 \\
\hline 1997 & 503 & 143 & 28.4 \\
\hline 1998 & 521 & 115 & 22.1 \\
\hline 1999 & 637 & 161 & 25.3 \\
\hline 2000 & 564 & 152 & 27.0 \\
\hline \multicolumn{4}{|c|}{ Papergivers } \\
\hline 1971 & 552 & 43 & 7.8 \\
\hline 1981 & 520 & 98 & 18.8 \\
\hline 1991 & 1940 & 512 & 26.4 \\
\hline 1992 & 1986 & 445 & 22.5 \\
\hline 1993 & 2053 & 525 & 25.6 \\
\hline 1994 & 2200 & 576 & 26.2 \\
\hline 1995 & 2160 & 598 & 27.7 \\
\hline 1996 & 2414 & 781 & 32.4 \\
\hline 1997 & 2419 & 669 & 27.7 \\
\hline 1998 & 2825 & 811 & 28.7 \\
\hline 1999 & 2809 & 789 & 28.1 \\
\hline 2000 & 2579 & 724 & 28.1 \\
\hline \multicolumn{4}{|c|}{ Discussants } \\
\hline 1971 & $1 \overline{84}$ & 13 & 7.1 \\
\hline 1981 & 161 & 28 & 17.4 \\
\hline 1991 & 455 & 120 & 26.4 \\
\hline 1992 & 568 & 118 & 20.8 \\
\hline 1993 & 521 & 152 & 29.2 \\
\hline 1994 & 594 & 157 & 26.4 \\
\hline 1995 & 583 & 157 & 26.9 \\
\hline 1996 & 574 & 142 & 24.7 \\
\hline 1997 & 575 & 161 & 28.0 \\
\hline 1998 & 708 & 183 & 25.8 \\
\hline 1999 & 630 & 171 & 27.1 \\
\hline 2000 & 605 & 159 & 23.2 \\
\hline
\end{tabular}

1997: 38.0\%, 40.4\%; 1998: 33.8\%, 43.7\%; 1999: 35.6\%, 45.6\%).

the program. At the 2000 meeting, women were $29.7 \%$ of those making presentations (138 out of 465 ) (cf., $28.1 \%$ for traditional paper presentations).

The divisions with the strongest female representation were Foundations of Political Theory*; Normative Political Theory*; Undergraduate Education*; Politics of Communist and Former Communist
Countries; Politics and Society in Western Europe*; International Collaboration*; Law and Courts; Urban Politics*; Women and Politics*; Religion and Politics; Political Organization and Parties; Political Communication; New Political Science*; and Ecological and Transformational Politics. ( ${ }^{*}=$ headed by women.)

The divisions with the weakest female representation in 2000 were Formal Political Theory; Political Economy; Political Methodology; Comparative Politics of Advanced Industrial Societies; International Security; Domestic Sources of Foreign Policy; Conflict Processes; Legislative Studies*; Presidency Research; Pulic Policy; State Politics and Policy*; Representation and Electoral Systems; Public Opinion and Political Participation; Science, Technology, and Environmental Politics; Information Technology and Politics; and Interdisciplinary Approaches to International History and Politics.

Among the predominantly female panels (omitting the panels in the Women and Politics section) were Roundtable on Simone de Beauvoir and Political Theory; Politics in Feminist Theory; Comparing Gendered Debates on Political Representation; Citizenship, Gender, and Work; Women Transforming Congress: Gender Analyses of Institutional Life; Citizens, Groups, and Courts: Opportunities for Influence; Comparative Analysis of Morality Issues in Urban Contexts; Engaging the Community: Local Policy and Participation Strategies; and "Sexual Citizenship" and Redistribution: Feminist and Lesbian and Gay Rights Perspectives.

Panels lopsidedly "stag" included Political Theory and International Relations: Exploring and Bridging the Gap; Might and Right; Roundtable on Democracy and the Reconstitution of Moral Order; Institutional Design; How Frames Shape 
Political Understanding, Opinions, and Discourse; The Political Economy of Constitutional Design and Evolution; Parties and Legislatures; Computational Approaches to Political Economy; Puzzles in American Political Development; Forecasting the 2000 American National Elections; Challenges to the Conventional Curriculum: Reports Across the Discipline; Theory and Evidence in Comparative Politics; The New Political Economy and Federalism; The Politics of Electoral Institution Transparency in Developing Democracies; The Political Economy of European Taxation in the 1990s; Perpetrator Networks: The Institutionalization of Anti-Jewish Policy in Western Europe, 1940-1942; Financial Liberalization and Currency Policy; The Political Economy of International Money and Finance; Strategies of Peacebuilding; Clausewitz After the Cold War: Assessing
Relevance for the Theory and Teaching of War; Domestic Cartelization and External Overexpansion: Myths of Empire and Recent Research; Selection Effects and World Politics; Considering Selection Effects and Strategic Interaction in International Conflict Research; Models of International Conflict; The Origins and Escalation of Crises; Alliances and Conflict: Shields or Handcuffs; Statistical Methods in International Relations; Partisanship and Representation in Legislatures; Legislative Representation and Public Policy; Presidential Power and Character; American Politics after Clinton; Reinventing State and Local Government; Contemporary Issues in Environmental Policy; Policy Transfer and Institutional Design; The Political Consequences of School Choice; Do Institutions Matter? Politics, Policy, and Performance; Perspectives on Learning,
Adaptation, and Policy Change; Courts and Judicial Policy: Theoretical and Comparative Perspectives; Current and Enduring Intergovernmental Issues in American Federalism: State Public Policy; Mixed Electoral Systems and Their Consequences; Advances in Redistricting Analysis; From Plurality to Proportional Representation: The Westminster System in Transition?; Roundtable on Contemporary American Political Parties: Fiftieth Anniversary Commemoration of the APSA Responsible Parties Report; Elites and Masses in Party Transformations; Money and Elections; The Next Wave in Experimental Voting Studies; The Recipe for Winning Elections; Social Influences and Political Beliefs; Covering Social Policy; Watershed Partnerships: Assessing a New Model of Environmental Policy; and Information Technology and Political Science Research. 
Colleges and Universities Submitting Names

Minority Identification Project

American Political Science Association

Spring 1999-Spring 2000

Is Your School Listed?

If not, ask your chair to contact APSA to get involved. More info can be found on www.apsanet.org/minority

University of Arkansas-Little Rock Beloit College $\bullet$ California State University, Long Beach University of California, Irvine University of California, Los Angeles University of California, San Diego University of California, Santa Barbara $\bullet$ Carleton College University of Chicago Colgate University University of Colorado, Boulder Columbia University - Drake University • Duke University • Emory University • Florida International University $\bullet$ Hamilton College $\bullet$ Harvard University $\bullet$ Haverford College University of Hawaii, Hilo Humboldt State University University of Illinois, UrbanaChampaign Indiana University, Bloomington lowa State University University of lowa Loyola University, Chicago Loyola University, New Orleans University of Maryland Massachusetts Institute of Technology $\bullet$ University of Michigan, Ann Arbor Millikin University University of Minnesota, Minneapolis Mississippi College $\bullet$ University of Missouri, Columbia University of Missouri, St. Louis North Carolina State University - University of North Carolina, Greensboro Northeastern Illinois University University of Notre Dame Ohio State University Oklahoma City University University of Oklahoma Pennsylvania State University University of Pennsylvania Ramapo College of New Jersey Rhodes College Rutgers University, New Brunswick $\bullet$ College of Saint Benedict University of South Carolina, Columbia $\bullet$ University of Southern California Southern University University of Southwestern Louisiana Stanford University Syracuse University Texas A\&M University, College Station Texas A\&M University, Corpus Christi Tufts University University of New Mexico Western Washington University

MID is now on line! Log on to www.apsanet.org/myAPSA

to enter students via the web! 